\title{
Model Policy Allocation Of Village Fund Assistance To Integrate Value Of Local Values In The Implementation of Decentralization On Local Politics In The Pariaman City
}

\author{
Tamrin \\ Department of Political Science, Faculty of Social and Political Sciences \\ Andalas University \\ Padang, Indonesia \\ Email: tamrin@fisip.unand.ac.id
}

\begin{abstract}
There is a relationship between decentralization and local politics. Decentralization is a power dissipation by the government internally, while local politics itself is the power of power in the spatial dimension, as well as the social-cultural boundaries that surround it. The function of local politics is as a means of learning to democracy and foster community capacity to manage the power that the central government is emitting to the region based on the environmental conditions of the region. However, in practice there is a missing link between democratic practices running at the national and local levels. The practice of procedural democracy in the form of a direct leader electoral system and the form of indirect policy formulation do not go hand in hand with deliberative democratic practices at the local level that have the characteristics of indirect leader selection as well as the form of decision-making done directly. Although these two forms of democracy are acknowledged in the precepts of Pancasila governing the principle of representation and consent, the practice of democracy is exercised more in the form of representative democracy and the exclusion of lokal values in the practice of democracy in Indonesia. This has implications on the form of concerns of integrating lokal communities at the national level through the simplification of village governance systems, such as the reluctance of lokal communities in West Sumatra to dialogue and finding mutually agreed solutions to customary nagari arranged by Law No.6 / 2014 on village governance. The following paper describes the policy model of the Pariaman City administration in allocating village funds for fiscal year 2016 and 2017 as a form of decentralization implementation in local politics, in order to become a model of the village (nagari) in West Sumatra that floats the form of lokal wisdom in the management of the citys rural government. Through the use of descriptive qualitative research methods, the conclusion is that the policy policy not only changes the expected economic development output orientation from the implementation of the policy but also encourages the parties involved in the conflict of interest of this development activity to engage in dialogue and accept mutual agreement as a constructive conflict mechanism in sustainable development
\end{abstract}

Keywords: Decentralization, Local Politics, Sustainable Development

\section{INTRODUCTION}

Local wisdom is a local idea that is wise, full of wisdom, good value that is embedded and followed by members of the community. Local wisdom can also be interpreted as life and science gameplay as well as various life strategies that manifest activities done by local communities in answering various problems in fulfilling their needs (Puguh, 2010 in Gitosaputro,
2015). Local wisdom is a product of cultural products of the past which is used as the guidance of continuous life, needed knowledge and understanding of cultural values as a local knowledge that has been integrated in the beliefs, norms and cultures expressed in tradition, myth.Another term local wisdomis local knowledge and local intelligence (local genius), local genius is referred to as local identity which causes the nation / society is able to absorb and cultivate foreign culture in accordance with the character and ability himself (Gitosaputro, 2015; 103). 
Local identity is not something static, but something dynamic follows the political objectives. This opinion is shared by both supporters and opponents of municipalamalgamation, municipal amalgamation increases the efficiency and effectiveness of government structures due to the abandonment of old cultural identity. This causes local identity to be influenced by external factors of external discourse, especially from political actors who use it for policy development purposes (Terlow, 2016: 938).The issue of selfidentity becomes the main issue of policy change, such as the policy of village amalgamation.Resistance to municipal amalgamation arose from the threat of loss of old cultural identities. If the merger of the new nagari fails to establish a new identity or new values as old identity as a primary identity will defeat a new identity as a secondary identity. Furthermore, the internal orientation within each individual or group in this primary identity encourages the orientation of each group in the formulation of public policy, resulting in a conflict between the expanding village (nagari). This local identity is conceptualized as a fixed and unchanging object as a result of the rest of the past process, and is shaped and influenced by different actors who encourage or use it to support local policies

As democracy consolidation is marked by the issuance of Law No.6 / 2014, the opportunity to carry out the nagari in a broader context is more open. Even in Article 6 paragraph 1 this Law is declared "[d]esa consist of indigenous villages and villages." The affirmation of village or nagari transformation into nagariadat(customary village) is also stated in Article 28 PP No.43 / 2014 on the implementation of village law. With the existence of these articles provide opportunities to the Minang community in West Sumatera province to develop their nagaribased on custom and existing culture. Especially with the traditional conception of mutual nagari brings the message that the development of nagariadat is very dependent on how people in nagari address this opportunity. The choice for the implementation of the nagariadat does not mean eliminating the substance of the lowest modern governance. The difference is in the proportionality of the execution of the existing authority in the nagariwhich is certainly more directed to the implementation of socio-cultural aspects. Moreover, so far the authority of nagari in the socio-cultural context is not clear although there is government recognition related to the right of origin.

Based on Article 35 of PP No.43 / 2014, the implementation of this right of origin gives hope for the people of the nagari to exercise its customary authority which is increasingly eroded by the times. The stated rights of the nagari origins include customary law institutions, traditional tenure ownership, ulayat(collective) land management, filling of the wali nagari (head of village) and its equipment and the filling of indigenous organizations and institutions. So far, the right of the origin can never be implemented by the Government of the Provincial Region of West Sumatra has not been able to describe what kind of traditional nagari desired by the change of policy of Village Government N0. 6/2014 in accordance with the traditional characteristics of mutual nagari (adat(customs) is limited to nagari). The same tendency is also seen in some districts / cities in West Sumatra. In Kabupaten Pasaman, for example, until now there has been no discussion from the district government and DPRD to make the lowest administrative unit into the nagari adat Many district governments in West Sumatra are not so interested in the opportunity to implement the nagari adat. "Ninik mamak" (adat leaders) incorporated in the Kerapatan Adat Nagari (Nagari Customary Meeting) in Solok District is not interested in choosing the option to organize this traditional nagari. There has been no deep discussion related to the transformation to the Nagari"(Tamrin, 2016)

This prompted the village administration in Pariaman City to use the village fund allocation in 2016 for the development of local wisdom in village governance through the use of funds for operational funding of village dubalang / 
Satlinmas and Barakai. Despite the amalgamation of korong(jorong) in some villages in Kota Pariaman into new villages, some of the newly formed jorongvillages are not separated from the local customary institutions (KAN) which unite themselves in an old nagari. The failure to establish a new identity within the village resulting from the amalgamation of the jorong allows them to return to the local identity of the old nagari that unites them in an old customary institution (KAN). The policy of regional expansion for the purpose of efficiency of governance does not affect their local identity as a nagari. The use of village funding allocations in the process of developing local wisdom in the village of Pariaman is not only intended as an example for other villages, but also differentiates the village position in Pariaman city with other villages in West Sumatra province.

Pariaman City has a different village government system from other village government in West Sumatra, this difference is seen the position of the village in the City of Pariaman is in the area of the City and led by the Mayor who has authority in determining the village head as village leaders (kelurahan). In this case, more rule changes occur in rules at the action level than rules at the policy or constitution level, the process of codifying the rules in formal and legal form at the constitutional level requires the formulation of policies involving various interests. the formulation of a new policy indicates something is wrong in the old policy. This error is mainly due to the output generated by the old policy of not reaching the expected output targets or impacts that disturb the balance of the environment, such as social order or environmental sustainability. The following article describes the form of local wisdom model in the Pariaman City fund allocation activity program in 2016 as a form of strengthening the rules of the game at the policy level against the rules, norms and values prevailing in society, based on the policy formulation process that involves the competition of various forms of social capital owned development actors involved

\section{LITERATURE REVIEW}

Forms of local wisdom in society can be values, norms, ethics, beliefs, customs, customary laws and special rules (Gitosaputro, 2015: 106). From various forms of local wisdom, this gives birth to different functions, including: first, functions for conservation and conservation of natural resources; second, functioning for the development of human resources; third, to develop the culture and science; fourth, serves as advocacy, trust, literature and abstinence; fifth, social significance such as communal relation of kin; fifth, meaningful social; sixth, meaningful ethics and morals; seventh, political meaning. Values, norms as a form of local wisdom are forms of rules that already exist in society, but have different levels of abstraction in their use. Values are abstract principles of behavior, actors are related to the value emotionally and embraced through the process of socialization (impregnation) and socialization, such as the value of justice, freedom, honesty (integrity) While the norm is a concrete form of value, value is more general agreement and allows different norms in the translation. This value study involves explaining attitudes, behaviors that involve the psychological aspect as well as the desired interaction and social structure in the future (Rusadi Kantaprawira 1987: 49).

Model is a form of study of a particular object that can bridge various knowledge, useful for decision-making purposes and then the decision has an impact on existing social order (Hall 2015: 62). The model is a reflection of reality, and can also be referred to as a map depicting the relationship of various concepts within it or as a narrative for a particular group that describes the complexity of various relationships in it, such as individual relationships with groups and public policy in the formation of local wisdom. There is an individual relationship, a group as a foundation of scholarship that explains the model of local wisdom, besides that there is also the influence of political policy that gives effect to the form and development of local identity as another term of local wisdom. Some scientific foundations of local wisdom are formed at individual and group level (Ridwan, 2007 in mardikanto, 2013) 
At the level of individual local wisdom develops and persists through several processes, including: first, selective attention, in which a person conducts screening of appropriate stimuli and touches feelings; second, appraisal, in the form of a psychological mechanism for assessing incoming information ,; third, concept formation and categorization, the provision of ways to organize differences in behavioral teachings into a number of categories; fourth, attributes, in the form of providing an important function in life to organize information that can control intention with behavior; fifth, emotion, a drive to do something. While local wisdom at the level of the group is a form of community habits that show the same understanding about something, caused by the existence of a setting as a spirit against ideal behavior in the interaction of groups in society (Wirawan, 1992 in Mardikanto, 2013).

In a transitional society, democratic transition in Indonesia requires a model as a form of communication in explaining the complexity of the relationships of various concepts in it. In the implementation of democracy there is often a missing link between written document and operationalization of the concept of democracy in the field. Democratic practice in the field influenced by various factors, including the political structure and political culture of society. This implies the implications of non-alignment of practice with the wishes made by constitution-makers The idea of democracy listed in the mukaddimah(introduction) of the 1945 Constitution is that democracy differs from the deliberative implementation of Indonesian democracy.Both democracy practices are acknowledged in Indonesia through the implementation of Sila 4 Pancasila, "Citizenship Led by Wisdom of Wisdom in the Deliberation of Representatives", although in the implementation of Sila 4 Pancasila the form of representative democracy is more implemented in the Indonesian political system than the form of deliberative democracy.

The idea of procedural democracy is drawn from the equality of democracy between the opening of the 1945 Constitution and the
Declaration of Independence of the United States, in which there is the idea of state governing the common point of all elements of the nation in the form of the Bhineka Tunggal Ika motto taken from E Pluribus Unum, periodic government. Although the form of the direct election system initiated by the drafters of the Constitution in the early independence cannot be implemented at the time, due to the low educational background of the community and the limited infrastructure of the Indonesian government, it is also called the first country in the world to emulate the model of democracy applied in the United States, followed by the Philippines, Taiwan and South Korea, (Muslim Mufti, 2016: 53).

The difference between the two forms of democracy is explained by Held based on criteria for the selection of leaders and decision-making processes (Mariana, 2008: 54). Procedural democracy emphasizes the process of direct election of leaders (elections) and indirect decision-making through people's representatives in the legislature. While deliberative democracy has the characteristics of leader election indirectly through the representatives of families, tribes in custom institutions and direct decision-making (deliberative) The impact of differences between the two democratic practices in the political system of Indonesia between political shock occurred in the form of conflict between modern political institutions with traditional political institutions, such as the conflict between the Head of Village result of direct election with Bamus as a representation of community leaders and customary institutions

According to Veblen, environmental factors and institutions affect economic phenomena, changes in community behavior are determined circumstances and the environment. This influence can be seen from the conditions of social and political structures to the process of economic distortion, while the circumstances and environment it called as "institution" (Deliarnov, 2004). Meanwhile, according to Commons the institution have long existed in the community in the form of conventions, the human behavior is 
more stable and tend to recur and become shade and obstacles for the individual. In society there is a norm as a rule derived from the prevailing value in a society, norms derived values and can be justified based on the values that prevail in the society. While rules that can not be justified according to the prevailing values in society are called conventions, even though conventions are made on the basis of collective agreements but require order and predictability to avoid chaos, such as the rules of the left wheel for motorists in Indonesia.

Institutions as norms and values can be interpreted as arrangements based on consensus or behavior patterns and norms that are mutually agreed upon, generally informal in nature in the family, society, customs and so on. Although social institutions are concerned with problemsolvingbut these social institutions do not move on their own but require an external (usually state-owned) authority to impose established rules. Schotter defines social institutions as "a regularity in social behavior that is specific to recurrent situations, and is either self-policed or policied by some external authority". Whereas the practice of social institutions requires reciprocity and solidarity, Hagner (1986) defines reciprocity as the hope of giving something to accept something slow or immediate (Reciprocity means that the givers expect to receive something in return sooner or later). Solidarity contains a broader sense, "solidarity has elements of altruism, loyalty, and reciprocity".

Behavior of solidarity does not always expect a reward, although the reward is not comparable or should be equivalent, as a polite behavior does not necessarily receive a higher solidarity response from others. If there are people behaving in accordance with norms and conventions, then he received an award from the community, but if there is a deviation then he did not get a clear sanction. Sanctions apply if the norms and conventions are changed to a clearer legal rule "rules of the game". Institutional characteristics according to Bogason (2000), among others; (1) there is a structure based on the interaction of actors; (2) a shared understanding of values, and (3) the pressure to behave in accordance with the agreed. Understanding institutions here are the values, norms, habits, cultures that are inherent in society. The inherent nature of the institution is easy to predict, more stable and easy to apply to repetitive situations.

According to Bogason (2000) there are three levels of rules; (1) the level of action; (2) the level of collective action; (3) the constitutional level. At the action level, the rules directly affect the real action, usually there are rules of conduct or standard rules (SOP). At the collective level of action, rules are expected to affect future rules and are often referred to as policies. Whereas if written formally and codified, then the future dosage is constitutionally as the principle of decision-making, such as democratic principles. Values and norms as a form of local wisdom also serves as a mechanism for conflict resolution, value and norms prevailing in society can lead the perpetrators of the conflict to dialogue and accept the outcome of the agreement with the dialogue. In this case there are two forms of conflict, such as constructive conflict and destructive conflict. Destructive conflict arises if the values that bind the community to engage in dialogue and accept new agreements are absent or too weak to withstand the pressure of conflict resolution destructively.Constructive conflict (constructive conflict ) able to encourage conflict actors to engage in dialogue and accept collective agreements as conflict solutions. This pattern differs from a form of destructive conflict that wants one party to lose or lose by another involved in the conflict. Conflict resolution resolves constructively if there is co-operation and co-ownership of the environment, and encourages the parties involved not to damage the environment in the settlement of conflict of interest among parties to the conflict on the basis of mutually agreed value.

In this case, development outputs have environmental impacts and encourage local communities (adat) to reject government policies that are perceived as destructive of social and 
environmental order, government conflicts with communities based on different views of development and environment orientation. On the one hand customary values as justification of norms require conservation as well as free from the intervention of political authority centralized by the central government to the regions, while on the other hand the development view explains that the results obtained from development can replace the lost resources in the environment (Davidson, 2014: 3 ). It is necessary to change the orientation of policy output into the form of rules, norms and values that can bring closer relations between government and society, so that the orientation of development and the environment is transformed into a joint ownership of the environment for development purposes. While the change of policy orientation from the output target to the formulation of rules, norms and values can lead to the orientation of sustainable development as well as the development of values that bind all development actors in an agreement in case of a conflict of interest. Joint ownership emerges in the form of human capital at the time after the natural disaster (environment) is over, and it gives birth to the opportunity of the owner of cultural capital who has knowledge of local wisdom to formulate a new policy in line with local values of arrangement of the environment

\section{METHODS}

This research uses qualitative approach with grounded theory technique. The use of this approach and technique is reasonable because the researcher wants to explain how the implementation of government affairs at the lowest level and the sociological and political reasons in the implementation of the village or nagari in accordance with Law No. 6/2014 on the village. To obtain the primary data, then used indepth interview technique, observation and documentation study. Qualitative research was chosen because this study has a more diverse approach than quantitative research (Creswell, 2012). In addition, qualitative research aims to understand the overall social dynamics through observation of behaviors, actions and objectives with a more natural method. To that end, this study will observe a problem related to the role or action of certain individuals. While the unit of analysis in this study are the Chairman of the Density of Adat Nagari (KAN) and the Village Head that is in the village in Pariaman City.

Furthermore, the data that have been obtained will then be analyzed in depth with the technique of drawing conclusions based on the analysis of the category of the village as well as the subjective category for the purpose of the research. Analyzes are done based on informant views that have been validated by using triangulation method. Triangulation conducted leads to crosscheck the validity of data sources, discussion of researcher colleagues and concepts and examination of theories used. The conclusion of this analysis is a combination of data obtained from informan and researcher data. Furthermore, reduced and simplified data is converted and exposed by describing empirical reality as a model. This study uses case studies based on research objectives to see the nature behind the formulation of policy development of the value of local wisdom in the form of norms as the rules of the game governing individual behavior in development in Pariaman City, and the complexity of various areas of study in influencing the form of local wisdom community

Data was collected by in-depth interviews, Focus Group Discussion, observation and documentation study. Techniques and selection of research informants are based on their criteria that are considered to understand the phenomenon being studied, especially those who are in the sphere of policymakers, nagari government organizers, adat (customs) leaders and community leaders in the nagari. Selection of informants as a source of data in this study is based on the principle of the subject who mastered the problem, have data, and willing to provide complete and accurate informants. For the purposes of more intensive interviews, the informants will be divided into two, [1] informant observer and [2] informant of the perpetrator. The technique of selecting the informant uses purposive and snowballing techniques which will also be adjusted to the conditions of the field (Afrizal, 2014). 
Furthermore, data collection in this study was conducted in four ways as follows. (1) Indepth Interview. In-depth interviews were conducted on informants who understood the phenomena related to the problems studied. This interview was conducted using two methods, namely structured interviews by preparing an interview guide that helps researchers get the data sought. it is also used unstructured interview method that is done freely not tied to the interview guide but still focus on the problem under study. This aims to complete the data from structured interviews that have been done. ; (2) Observation; (3) Documentation Study

The data will be organized by creating a structured summary in the form of text, matrix, formulation of the model that has been structured. To ensure the validity of data, in this study only use the technique of internal validity. Here are the strategies to be implemented,: (a). Triangulation of data; research data that has been obtained through various sources for the results of interviews, observation, and documentation can be analyzed thoroughly,; (b) Member checking; informants will check the entire process of data analysis. The results of interviews with informants such as interpretation results will be discussed simultaneously; (c) Peer examination.

\section{RESULTS}

Pariaman City is the only autonomous city in West Sumatera after the reformation in 2002. Pariaman itself was previously part of Padang Pariaman Regency and became the Central Government (Ibukabupaten) of Padang Pariaman. Prior to the establishment of Law No. 5/1999 on Village Administration, the Padang Pariaman District and other areas in West Sumatra consisted of several Nagari Government as the lowest administrative unit with the territory of the customary law community. Furthermore, the area of Pariaman City itself, which was then a part of Padang Pariaman Regency, consists of 11 Nagari Governments, where each Nagari Government has several areas called korongkorong (jorong). However, since the birth of Law no. 5 of 1979 which uniforms the lowest form of
Government in Indonesia into a village, then there was a change in the form of the lowest government in West Sumatera that replaced the system of Nagari Government into the Village Government system. The interesting thing about this policy is that the West Sumatran government then responded to the policy by making the lowest (village level) Village Administration at the funnel level, and not at the Nagari level. The pre-existing korong (jorong) as part of the territory of each Nagari, divided into respectively Village Government (lowest) in West Sumatra, while the previous Nagari Government was the lowest government unit then abolished. Furthermore, this condition also resulted in the change of form of the lowest government in Padang Pariaman regency, including in the area of Pariaman sub-district (Pariaman City area today) at that time.

These changes include the 11 previous Nagari Governments as the lowest Government units, abolished, and the funnel (jorong) or a combination of several mouthpieces in each of the Nagari, each becoming the Village Government (the lowest). Since then, the Pariaman sub-district (Pariaman City area at present) consists of several villages as the lowest government unit whose number is more than the previous Nagari Government.While the reasons for government, customary apparatus, and the public accept policy to make the funnel as the basis of Village Government in Pariaman is the factor of obtaining village funds. community considerations together with the Government of West Sumatra Province in general due to want to maximize the acquisition of funds of village assistance (Bandes) is large enough from the Central Government for the development of the village post-birth Act No. 5 of 1979. One of the considerations submitted when it is if still keep the region Nagari as the lowest government base (village), the number of bandes received will be small, while the number of Nagari as the lowest unit of government in West Sumatra at that time is very small compared to the lowest number of government units in other provinces. This is because the size of the territory of one Nagari geographically in West Sumatra when it is very wide. Moreover, the condition of most areas 
Nagari when it is also quite apprehensive because it is still minimal infrastructure ${ }^{1}$

The consideration of the West Sumatera Provincial Government then led to various parties and communities in Korong (village), in Nagari, traditional leaders, and the Government in Pariaman when it agreed not to make Nagari as the base of the Village Administration, but to make every existing funnel in each of the Nagaris as the basis for the lowest (village) administrative area in order to receive more village grants. In addition, although this policy resulted in the disappearance of the previous 11 Nagari Administration as the lowest administrative unit in Pariaman, the existence of Nagari as a territory of indigenous peoples (kenagarian /adat village) is still maintained and recognized by the Government through customary institutions in Nagari Customary Density KAN) in each of the 11 Nagari. In this case, the Kerapatan Adat Nagari(KAN) as the legislative body consists of traditional apparatus such as Datuak / Penghulu, Niniak Mamak, Alim Ulama (Labay, Imam, Khati '), Urang Tuo, and Kapalo Mudo from each tribe and from each village (korong) which has the authority and functions to manage, carry out and maintain sako, pusako, customs, culture, values and customary order, and customary property within the territory of customary law community (kenagarian / desa adat) each.

The policy of splitting the existing jungles in each Nagari into the Village Government at that time was only within the limits of splitting the functions of the administrative unit alone, while the functioning of the adat, the order of customary values, the elements of traditional apparatus within the territory of indigenous peoples ( customary village) is not expanded and maintained. This has led to some villages formerly a belligerent of one Nagari, with customary authority still one based on KAN institutions whose existence is still recognized as an authority that guards and maintains

\footnotetext{
${ }^{1}$ Interviews wirh Masril, Dt. Rangkayo Rajo Putiah, Head of KAN V Koto Air Pampan, 20th of Oktober 2017, di his house
}

customary order in its local Kenagarian (adat) area. This was also the reason for the acceptance of the policy of dividing the village into a village by various parties at that time, due to the existence of each Nagari 11 as a customary law community in Pariaman still maintained through KAN, and not participated in every village. This affects the customary values and life spirits of the Nagari in each village within a territory of indigenous peoples (kenagarian / desa adat) to be able to grow and color the lives of the people, even though the Nagari Government no longer exists. $^{2}$

In the next development, in 1986 the Central Government policy was born to make Pariaman District as the mother of Padang Pariaman District become Administrative City (Kotif) Pariaman. This led to the birth of a rule that ordered some villages in the center of Kotif Pariaman into Kelurahan. The follow up of this provision is that some villages in Kotif Pariaman (capital of Padang Pariaman District) were changed to Kelurahan, and the rest still retained the Village Government. Since then, there are generally two forms of lowest government in Pariaman namely Desa andKelurahan. The existence of these two forms of the lowest government in its development continues to continue so that the expansion of Kotif Pariaman from Padang Pariaman to Pariaman City in 2002. At the beginning of its establishment, the City Government of Pariaman plans to change most of the existing villages in Pariaman City into Kelurahan, the lowest government in Pariaman City can be uniform to the Village Government. However, this plan was not implemented because of the emergence of rejection by the majority of the community at the village level because this policy is considered to eliminate the local autonomy function of the village such as the autonomy of the arrangement of community life in the village. Furthermore, in 2007 the policy of West Sumatra Province on the Government of Nagari reaffirmed that the entire area of the City / District in West Sumatra except Mentawai

\footnotetext{
${ }^{2}$ Interviews with Masri Muchtar, Head of village Desa Batang Tajongkek, 18 October 2017, at central mosque of Desa Batang Tajongkek.
} 
District, making the lowest form of government becomes Nagari Government. Pariaman City Government together with the community still agreed to maintain the Village and Village system because it is considered more effective in the context of governance and community rather than re-unite existing villages / kelurahan to become 11 Nagari Government back. In this case there are two forms of the lowest government in Pariaman City to date that are still maintained, some are villages and others in the central Government (District Pariaman Tengah) in the form of government

Furthermore, KAN's position as an adat(customary) institution is in charge of each of the several villages within the territory of the customary law community (Kenagarian / Desa Adat).Some of which are (KAN) as a customary institution (Desa-Adat / Kenagarian) or the incarnation of Nagari has the authority to supervise / cover several villages, and there is no KAN in one village only within the territory of the customary law community (Kenagarian ). The territory of one Nagari does not consist of a single funnel, but consists of several funnel and then the funnel in one Nagari transformed into villages.The authority or authority possessed by KAN is only in the function of customary authority, such as safeguarding, managing and preserving and managing the affairs of sakopusako, customs, social / cultural system arrangements, Nagari ulayat property, and traditional art in the territory of customary law community / her escort. KAN membership consists of traditional tools such as Datuak/ penghulu, niniakmamak, alim ulama, urangtuo, kapalomudo, from each tribe and from every village (korong) in the territory of indigenous community / kenagarian community.

There are 11 Customary Institutions (Kenagarian) in Pariaman City today, social and cultural environmental factors affect the relationship between village government and customary institutions. Both of these factors influence the form of election of leaders and the process of formulating the policy as a form of democracy that is run on each village, it affects the form and implementation of local wisdom development activities in the village community.
Although there is a program form of local wisdom development activities among the various villages in Pariaman city, but the implementation of the activity program is different among each village. This distinction describes the form of norms in the implementation of the values of society, such as freedom, honesty, integrity, and others. In this case, the lowest government in Kenagarian (KAN) of Air Pampan, ie there are some villages in the center of the City which made some Village Government, and the rest remain with the form of Village Government. In its development, since Pariaman City blooms from Padang Pariaman Regency to Autonomous City in 2002, the number of Village and Village in Kenagarian V Koto Air Pampan also changed. And until now, in the territory of the customary law community of Kenagarian (KAN) V Koto Air Pampan consists of 11 Villages, and 6 Villages located in Pariaman Tengah District, one of them is Pauh Timur Village. Thus, the 11 sub-districts and six villages formerly part of the Nagari V Koto Air Pampan region.

From the existing findings there is the authority of customary institutions that exceed the authority of the village administration, this difference is influenced by the recruitment base of customary institutions and village government apparatus. Villages in Pariaman Timur and Pariaman Selatan sub-districts are categorized as village-nagari (adat) models, while villages in Kecamatan Paraiaman Tengah and Pariaman Utara are categorized as village-urban(dinas). model The rural-urban (dinas) and village-nagari (adat) categories are based on the political recruitment basis of traditional institutions and village government apparatuses, as well as decision-making processes. These two forms represent the influence of the implementation of democratic representation (procedural) as a form of implementation of national democracy with deliberative democracy (deliberative) as a form of local democracy implementation. Furthermore, the implementation of the form of democracy affects and is influenced by the development of local wisdom values in the community, where the program of development activities of local wisdom in the villages (adat) is more well run than the city-town (service) in Pariaman City. 
In rural-urban relationships between the nagari government and adat institutions are not running harmoniously, the program implementation of the allocation of village funds (ADD) is not through the results of deliberation with customary institutions. In contrast to the implementation of program activities in villages (adat) which involves the results of deliberations between the nagari government and the leaders of customary institutions through informal meetings in the implementation of local wisdom development activities, such as badoncek activities. Badoncek / barantam is a tradition donated money together to help villagers who baralek in the form of money, whose value can even up to 8 million and attended by the elements of traditional erection with the entire village community. Cooperation undertaken by the nagari government with customary institutions has resulted in a synergicity between development policies by the nagari government and local wisdom program development of customary institutions

The case that occurred in South Tungka Village, where all the customary devices also still have the authority and a very central role in the middle of the village community. It is also influenced by the existence of the Chairman of KAN Nagari Tungka which originated and domiciled from this South Tungka Village, including also other Datuak-Datuak most of which also originated and domiciled in Tungka Selatan Village because of the dominance of several tribes in the village. The existence of Datuak-Datuak(customary leaders) which also acts as an element of traditional tools in this village further strengthens their authority in the midst of society as a social leader. The traditional apparatus and Datuak-Datuakis very dominating in the community in solving every problem and problems that exist in the village, including in the implementation of Village Government. All elements of the customary tools including the Datuak-Datuak are involved and occupy all the institutions / community Organizations and Administration in the Village, such as in BPD, LPM, RPJM Team, Village Religious Development and Education Institution, and others. Even Chairman of BPD is currently held by the
Chairman of KAN. The consequence is that these customary apparatus are directly active and involved to synergize with the Village Government in implementing the Village Government such as decision making and village policy. This shows how the position of Adat (customary apparatus) is actually not separate from the village government. One of them is seen from the accommodation of customary values / norms in the formal rules of the Village Government with the establishment of Perdes (village regulation) Security and Village Order, and PerdesMaghrib Mengaji initiated on joint initiatives in the deliberations of customary and Datuak-Datuak instruments residing in BPD and other institutions in Village

In Desa Batang Tajongkek, for example, the implementation of various programs of development of local wisdom is inseparable from the background influence of the current Village Head who previously was Kapalo Mudo (element of traditional institutions) in the village. Prior to becoming a Village Chief, he was always entrusted with various positions of organization and government in the village such as the Chairman of LPM and Kaur Pemerintahan Desa(head of administration). In addition, he is always active and concerned in solving any problems that occur in the village along with other elements of traditional tools, including active and involved in the implementation of traditional and religious activities in the village. In fact, he became the Village Head after it was proposed from the deliberation of the elements of traditional tools, and earned him the most votes and was elected Head of the Village. Background as an element of traditional tools and other activities in the village problem since the former, made the Village Head is always in synergy and all elements of traditional tools in carrying out their leadership, so that various programs / policies or activities of development of local wisdom values from the management of Village Funds in Batang Tajongkek Village can grow and be implemented effectively.

Agreement on the ownership of shared values not only encourages the nagari (adat) and government communities in formulating mutually agreed development policies, but also 
enables the development of local wisdom to support development objectives. There is an increase in the level of economic welfare of the community from the implementation of the development of the allocation of village funds based on the value of this local wisdom in Tungka Selatan Village, Batang Tajongkek Village, Kampung Apar Village, and also in Talago Sariak Village, the development process of the Village Fund is done jointly by the workers originating from the original villagers who were paid. This can not only increase income for indigenous villagers, especially those who are unemployed by working in development activities, but also facilitate the circulation of the economy of the community through the procurement of goods for development purchased from stores / businesses residents in the village, such as procurement of gravel, sand, cement, and other goods and equipment so that the economic turnaround in the village is also increasing.

The deliberation as a form of recruitment of Village Head election is a model of Village Head election in Pariaman City, this model is a model of deliberative democracy (pemusyawaratan) developed in local community as a preliminary form of village head election conducted directly through the implementation of representative democracy implemented by the nagari government supported by all stakeholders. In the Village Head Elections, no Sumando people or outside entrants are required to fill the post, including filling in other government posts and Village Governments, except Sekdes (secretary of village government). Even if there are villagers who have just returned from the rantau, or rarely domiciled in the village nominally become the village head, usually will not be elected as the village head. As for every candidate for the village head who will progress must also have obtained the blessing of these customary devices. So whoever is elected head of the village, has a good relationship with these customary apparatus. Furthermore, the ninakmamak with the family / adat (adat tools) supports the implementation of policies on development activities in the village, such as willing to give up their land voluntarily used for village development. The participation of this development was born because they have been actively involved and participate in approving the birth of the policy, it is also seen in the taxation of $P B B$ (property tax) the Villagers who also can be realized well for the role and encouragement of the niniakmamak to the child / nephew / his family .. The devices adat is also always play a role in solving every problem / problem and decision making in governance of Desa (village).The decisions generated in Musrenbang nagari activity implicitly have to get agreement / approval from element of this tool as a form of customary leaders' involvement in the administration of nagarigovernment.

This deliberation also occurs in the form of strengthening of customary values / norms that are formalized into Perdes, such as the Prohibition of Gambling in the village of Kampung Apar. The idea to make the customary norm become Perdes is inseparable from the proposals of the traditional tools along with other elements of society in negotiations and intensive talks with Head of Village member of BPD in Wirid activity in Mosques / Mushala. This proposal was then discussed jointly by the Government, BPD, which also involved elements of traditional tools, and other elements of the community at LPM, so that the proposal was then agreed to be set to Perdes. The influence of indigenous peoples' power in slowing down the nagari government in Pariaman City is not only influenced by the dual roles of adat leaders as government apparatus, but is also influenced by the structure of customary institutions which have wider territories of authority than village administrations. The customary institution (KAN) is headed by a Chairman and Secretary, this institution has customary equipment, such as Niniak Mamak, Urang Tuo, Kapalo Mudo, Alim Ulama (Imam, Khati ', Labay, Imam spread in each village) as village apparatus, but they are more subject to the decision of customary institution than the Village Head if the decision concerns the affairs of customary institutions. This adat tool is involved in solving social problems that occur in the community, the dependence of the community on the traditional tools puts the adat on the traditional institutions more high than the village administration. 
Different conditions are seen in Tungkal Utara Village of Tungka Kenagarian where the KAN Chair is the same as South Tungka Village. Although adjacent to South Tungkal, but the development of local wisdom values less run in this North Tungkal Village. This is inseparable from the background of the elected village chief who had previously been domiciled in Rantau as a trader, and only a few years in the village. The election of the Village Head was inseparable from the strength of money he had in winning the Pilkades, and the Village Head was not synergistic with the elements of traditional tools in the village. This then affects the leadership of the Village Head who tend to be authoritarian and less involving the elements of traditional tools in the implementation of Village Government. For example, the existence of customary norms that regulate for every outsider who lives in the village, must first be settled first customary ceremony by Niniak Mamak. But this rule is about and is not enforced by the Village Head. As a result, the relationship between the Village Head and the traditional tool elements is always across, and there are often conflicts. Even the elements of this adat tool are no longer willing to participate and support every implementation of Village Government. This has an impact on the poor synergy between the Village Government and the elements of traditional apparatus, so that the development of local wisdom values is very difficult to achieve.

Coordination between customary institutions and village government in the program of local wisdom development activities does not occur in rural-urban areas, no village regulations (Perdes) are born as a reinforcement of local wisdom values that have been applicable in society. Some forms of local wisdom values that have been applied in the community, as well as experiencing strengthening of Perdes in villages such as the prohibition of gambling, adultery, disrupt the general public by performing a single orgen game crowd at night. Some of these restrictions constitute a form of customary law that has been applicable in the local community, but requires Perdes as a form of strengthening through sanctions imposed on violations committed. Some forms of sanctions are committed based on the agreement of customary tools, among which the sanctions are the most heavily excluded custom. The offender or his family is not ignored by the community, the customary devices with the community will not come if there is a family who died and organize the mandoa / mangaji event at his home. Likewise, if there is a family will get married, then the traditional tools with the community will not participate / did not come in every procession of traditional events baraleknya, including will not badoncek money for his family.

Sanctions are not included in customary activities as a form of exclusion from the community is the most severe form of customary law for violations of customary norms, other customary forms prevailing in society and experiencing strengthening Perdes is a habit of doing religious activities in the time of Magrib to Isa who was preceded with the activities of Salat, such as sharing together in the Mosque or at home with the family, Wirid Mingguan (weekly meeting) in Mosque / Mushala, studying together in the homes of the deceased, and forbidding visiting activities or receiving guests and other activities such as sitting in the shop, making entertainment, , and other hustle activities in public places during the time between Maghrib and Isyapraying. The values of Magrib Mengaji are also well known and became a habit when formerly when Banagari (villlagerness) lived in Pariaman, and this value is still quite developed in some other villages in Pariaman City such as Talago Sariak Village, Sungai Kasai Village, Naras I Village and Pauh Village East. These customs are still strongly adhered by the community and the Indigenous Devices of South Tungkal Village and other villages in Pariaman Selatan and East Pariaman Subdistricts, and made in the form of Perdes by the village administration and BPD based on the results of the compound of traditional tools with the village administration

The background of government apparatus and BPD from career positions such as teachers, civil servants and other government apparatuses in rural-urban areas in Pariaman Tengah and North Pariaman sub-districts do not allow the birth of Perdes as a strengthening of local wisdom, such as in Sungai Kasai Village which is 
still Kenagarian ( KAN) Kurai Spurs the reduction of customary values in the implementation of Village Government. formal positions in the village, none of the customary tools are members of BPD. The membership of BPD is dominated by public figures from among members of $D P R$ (legislative body), PNS (public servant), teachers, and others who are not from the village (sumando / pendatang). The same thing is happening in LPM institutions, these adat tools only play a role in customary activities such as traditional baralek events or religious events in Surau. Although adat values and norms still apply in this village community, but not strengthened by Perdes as the influence of the organization of village life

Lack of collective agreements on community-binding values encourages the destructive conflict in rural-urban rather than constructive conflict in rural-country. The case of Naras 1 village shows the presence of traditional leaders (niniak mamak) who also often gamble in village stalls, as well as the relationship between mamak and nephew can be said to have almost faded.In fact, between mamak and nephew or father and son gamble each other in the shop something that is common in this village. The relationship between village government and BPD is often conflict, such as Village Head and TPK of village fund management reported by BPD to law enforcement in the budget management issue of 2017. Although these customary tools are always invited in every Musrenbang, the role of role is passive as a tool of legitimacy decisions made by the village administration

To develop the values of local wisdom of Nagari people, the Pariaman City government together with the traditional leaders in LKAAM through the formation of Dubalang and Barakai.Dubalang tasked to maintain security and order, enforce the rules, and overcome social problems in the village community, but keep coordinating together with traditional tools in the village. So is the formation of Barakai whose job is now more as a janitor in the village. The establishment of Dubalang and Barakai has been done in all villages in Pariaman City since 2016 ago. In this case, each village is formed two Dubalang and one Barakai.Dubalang and Barakai is honored by the Village Government through the allocation of Village Fund for Rp. 300.000, (three hundred thousand rupiahs) for one Dubalang, and 600 thousand for one Barakai per month. The implementation of the Dubalang and Barakai program is almost the same in every village, and has been done in all villages in Kota Pariaman. The role and effectiveness of each Village has differences, these differences can be seen in the village-town model with villages.

The performance of each Dubalang and Barakai is influenced by their recruitment process, as well as the way they make decisions related to the performance of their main duties and functions as perngkat adat or governance within the village. The commitment of dubalang in the villages (adat) is done through a process of deliberation between customary institutions and village government, and is chosen based on their experience and courage in maintaining village order. The Dubalang in each of these villages are the initial settlers of disputes that occur in the community, after previously keeping in coordination with the customary devices. This happens in some villages in East Pariaman and South Pariaman, such as Batang Tajongkek Village, Kampung Apar village, South Tungka Village and Talago Sariak Village. While the recruitment process dubalang in rural-town (service) based on the initiative of the head of Village, and less well known before by the local community linggkungan. Dubalang in Naras Village is appointed directly by kepaladesa as the head of village without any discussion with the customary devices, so that people who occupy the position Dubalang tend to be very young and have difficulty in the role of security and order in the village. These dubalangs are often not appreciated and seem to allow violations of customary norms, this Naras 1 village clause also occurs in the village of Pauh Timur This has led to the occurrence of overlapping authority between dubalang and ninik mamak (existing leaders) in the settlement of family and community conflicts between dubalang and adat leaders (ni9nik mamak). Adat leaders are the first conflict settlers prior to their settlement by government 
agencies, while the village government can only finance dubalang. ${ }^{3}$

\section{Local Wisdom Model Implementation of 2016 Village Fund Allocation In Kota Pariaman}

\begin{tabular}{|l|l|l|}
\hline \multirow{2}{*}{$\begin{array}{l}\text { Local } \\
\text { Wisdom } \\
\text { Model }\end{array}$} & $\begin{array}{l}\text { Village } \\
\text { Model }\end{array}$ & \multicolumn{2}{|l|}{ Village } & $\begin{array}{l}\text { Local } \\
\text { Community } \\
\text { Village }\end{array}$ \\
\cline { 2 - 3 } Value & $\begin{array}{l}\text { Individual } \\
\text { oriented } \\
\text { value }\end{array}$ & $\begin{array}{l}\text { Collective } \\
\text { oriented value }\end{array}$ \\
\hline Norms & $\begin{array}{l}\text { Reciprocity } \\
\text { norms }\end{array}$ & Loyality norms \\
\hline Ethics & $\begin{array}{l}\text { Situational } \\
\text { ethics }\end{array}$ & $\begin{array}{l}\text { Permanent } \\
\text { ethics }\end{array}$ \\
\hline Trust & Centralized & Decentralized \\
\hline Customs & $\begin{array}{l}\text { Destructive } \\
\text { conflict }\end{array}$ & $\begin{array}{l}\text { Constructive } \\
\text { conflict }\end{array}$ \\
\hline $\begin{array}{l}\text { Customary } \\
\text { law }\end{array}$ & Inclusive & Exclusive \\
\hline $\begin{array}{l}\text { Special } \\
\text { rules }\end{array}$ & Tolerance & Discriminative \\
\hline
\end{tabular}

\section{DISCUSSION}

The municipal amalgamation policy of korong-korong (jorong) in the city of Pariaman into the village results the problem of local identity of the community who joined the other funnel in a Nagari that serves not only as a unit of government administration, but also as a unity of indigenous peoples This inidvidu relationship within the indigenous group is a form the development of local wisdom values at the individual level into the group level through various uparaca and customary activities, such as the ceremony of Isra 'Mi'raj, the praying of death people , barundiang / badoncek in the activities of marriage and other forms of customary institutions. However, in conjunction with the purpose of development efficiency, regional division of jorong is transformed into a more

${ }^{3}$ Interviews with Syafwin, Head of LPM Desa Naras I, 18 Oktober 2017, at the office of Kepala Desa Naras I autonomous village. This government policy aim is not only a form of government management efficiency to be the lowest unit of community service, but also has implications for identity change local communities of the primary community in indigenous peoples became the local identity of secondary society as a new territory of government administration. Although the local identity of the indigenous peoples (nagari) in the city of Pariaman is the result of the past process, but its form and its development adjust to the government policy. The failure to establish new local identities in secondary societies encourages individuals within these communities to re-discover their primary local identity within indigenous groups. These disadvantages occur in the village communities in the city of Pariaman in the use of village allocation funds in 2016 compared with ruralurban communities, the inclusive nature of new values based on individual values orientations encourages the birth of norms -the norms based on the nature of resipsosity and situational enabling the birth of centralized authority compared with the villagers of the nagari(adat). However, the concentration of rural-urban village authority not only reduces group values as a form of the solidarity of norms prevailing in society but also reduces the support of customary institutions to the course of village government activities in the city of Pariaman caused by diminishing values which is mutually agreed upon in encouraging development actors to dialogue and accept the results of collective agreements if there is a development impact on social order and environmental preservation.

\section{CONCLUSIONS}

This research is conducted in 55 villages in Koata Pariaman which is assumed to be advanced in the implementation of nagari government based on the customs and culture of the society. There are several assumed villages that meet the criteria of the research location, from each village the villages are chosen to deliberately advance in the implementation of customs and culture in the fenced. This village was chosen from the village of the division of 11 old villages in Pariaman City, then the data 
collected in this village is compared with other villages categorized as villages close to the central government which is categorized as the original village before the expansion. From the results of this comparison found the pattern of similarities and different forms of development activities of local wisdom development programs, as well as the process of formulating the policy that is run. From the results of this comparison emerged village-town and village-nagari as a model of development of local wisdom in the policy of regional expansion and implementation of the allocation of village funds in 2016v in Pariaman City. Village-town is a village that is open to differences in social values and backgrounds in the process of political recruitment, the application of situational norms based on social dynamics that occur in society, is inclusive, but more centralized authority in village government institutions and produce forms destructive conflict if there is a losing party, has a high individual value orientation, as well as norms based on the attitude of profit and loss (reciprocity). While the characteristics of the villages (adat) is to have a group value orientation, norms based on the principle of solidarity, as well as ethics that are still biased judged from mutually agreed behaviors, upholding the principles of consent as a form of trust each other as a result of decentralization of authority, the perpetrator of the conflict to dialogue and accept mutual agreement, but is closed (exclusive) to differences in value and memeiliki rules khsusu political recruitment process that is exclusive.

\section{ACKNOWLEDGMENTS}

This article is part of a research report funded by the Ministry of Research and Technology and Higher Education through the Basic Research Scheme of State Universities' Higher Education Operations (BOPTN) in 2017 through the Institute of Research and Community Service of Andalas University. Acknowledgments were submitted to the Ministry of Research and Technology and Higher Education through Andalas University as a party involved in assisting the funding of this research, as well as 1 lecturer and 2 students involved in the process of collecting and analyzing this research data.

\section{REFERENCES}

Afrizal, (2014), Metode Penelitian Kualitatif: Mendorong Penggunaan Metode Penelitian Kualitatif dalam Berbagai Bidang Ilmu. PT. RadjaGrafindo.Jakarta.

Davidson, Kathryn, (2014 ), "A Typology to Categorize the Ideologies of Actors in the Sustainable Development Debate", Sustainabel Development. 22, 1-14

Deliarnov, (2006), Ekonomi Politik, Jakarta, Penerbit Erlangga

Gitosaputro, Sumaryo dan Kordiyana K. Rangga, (2015), Pengembangan dan Pemberdayaan Masyarakat, Konsep, Teori dan Aplikasinya di Era Otonomi Daerah, Yogyakarta, Graha Ilmu.

Hall, Damon M, Todd M. Swannack, Edi D.Lazarrus, Markus J Peterson, Susan J. Gilbertz, Cristi C. Horton, Tarla Rai Peterson, (2015), "Integrating Social Power and Political Influence into Models of Ecological Systems", European Journal of Sustainable Development, 4,2. 61-76

Kantaprawira, Rusadi, (1987), Aplikasi

Pendekatan Sistem dalam Ilmu-Ilmu Sosial, Jakarta, PT Bunda Karya.

Mariana, Dede and Caroline Paskarina, (2008),

Demokrasi \& Politik Desentralisasi, Graha Ilmu, Yogyakarta

Muslim Mufti, Didah Durrotun Naafisah, (2013), Teori-Teori Demokrasi, Bandung, Penerbit Pustaka Setia,

Tamrin, Yunita, Yoserizal, (2016), "Pengembangan Model Nagari Adat Di Bawah Rezim UU Desa Dan Implikasinya Dalam Penyelenggaraan Pemerintahan Terendah Di Sumatera Barat", Laporan Akhir PUPT Tahun Ke-2 Dari 2 Tahun Yang Direncanakan, Universitas Andalas h. 33

Terlow, Kees, (2017), “Territorial Changes and Changing Identities: how spatial identities are used in the up-scalling of lokal government in 